\title{
The influence of technological parameters of creams fermentation on formation of functional peculiarities of cultured butter
}

\author{
Lubov Musiy ${ }^{1}$, Orysia Tsisaryk ${ }^{1}$, Iryna Slyvka ${ }^{1}$, Oleg Galenko ${ }^{2}$
}

\author{
1 - Lviv national University of Veterinary Medicine and Biotechnologies named \\ after S.Z. Gzhytskyj, Lviv, Ukraine \\ 2 - National university of food technologies, Kyiv, Ukraine
}

\section{Keywords:}

Fermentation

Cream

Flora Danica

Lactobacillus

Acidophilus La-5

Butter

Fatty

Acid

Article history:

Received

14.05.2016

Received in revised

form 20.06.2016

Accepted

30.06.2016

\section{Corresponding}

author:

Musiy Lubov

E-mail:

musiyluba@ukr.net

\section{Abstract}

Introduction. The determining factors of cultured butter production is fermentation processes (selection starting cultures, their relations and determinations of optimal technological parameters of fermentation) and physical cream maturation.

Materials and methods. The activity of acid formation during cream fermentation was determined by volumetric change and active acidity. Number of viable cells Flora Danica and Lactobacillus acidophilus La-5 was calculated by sowing while using nutrient environment M17 Agar CM-0785 and Lactobacillus MRS Agar M 641-500G (Himedia). Fat acid composition of oil samples were investigated by gas-liquid chromatography using gas chromatograph Hewlett Packard HP-6890.

Results and discussion. The use of dairy products compositions in the manufacture along with some lactobacilli, containing monocultures of probiotic strains can become irreplaceable in terms of modern nutrition food with probiotic, health and given special properties.

Subject to the technological instructions recommended temperature fermentation and compromise temperature for microbial cultures selected drugs were chosen two temperatures 20 and $30{ }^{\circ} \mathrm{C}$ for cream fermentation. It was established that the highest growth rate recorded in titrated acidity cream sample, which was used for fermentation Flora Danica + Lactobacillus acidophilus La-5 and temperature $30^{\circ} \mathrm{C}$.

As the results demonstrated, like the joint cultivation Flora Danica + Lactobacillus acidophilus La-5 for fermentation temperature $30{ }^{\circ} \mathrm{C}$ shows the best dynamics of biomass growth for fermentation and physical maturation cream, because the concentration of viable cells in this version was the largest.

As for the content of fat acids that exhibit a strong biological effects, their contents showed a clear tendency for the sample of cultured butter rise, which used a combination of mixed cultures of mesophilic and thermophilic acidophilic bacillus fermentation and cream at temperature $30^{\circ} \mathrm{C}$.

Conclusions. The use of technology of cultured butter composition, composed of mixed cultures of mesophilic was proposed to use for the first time. 


\section{Introduction}

The role of probiotic products grows in the modern world daily. The demand of consumers for new nutrition products is very large; today the consumer ability of the world functional foods market is estimated about 1.4-1.7 million US dollars, from them $65 \%$ constitue functional milk products $[1,2,3]$. Milk and functional milk products, occupying a substantial place in the daily ration of Ukrainians, are on the one of the first positions among functional foods today, that prevents an origin and progress of dysbacteriosiss [4].

The correct choice of cultures for the fermented dairy product provides the obtaining of the product of certain type with the characteristic and rationed indexes of quality and forecast probiotic properties. The market of functional milk products with probiotics, mainly, is presented by soul-milk drinks of the functional setting. Cultured butter with the probiotic bacteria at the market of Ukraine, countries of the CIS and European Union is not presented. The usage of ferment compositions in the dairies production, that are next to certain lactic acid bacterias, contain monoculture of probiotic strains, that allows to get irreplaceable, from the point of view of modern dietetics, food product with probiotic, health and set of special properties [5]. While common cultivation of two cultures, the origin of both sunergism and antagonism is possible, that is why the necessary stage of experimental researches at the production of cultured butter is the feature stablishment of cross-coupling the cultures of Flora Danica and probiotic monoculture Lactobacillus acidophilus of probiotic strain La-5 at a cultivation in creams [6].

Cultured butter is an enough popular product in the European countries, unlike our state. The reason of such low demand of cultured butter in Ukraine are not only differences in tastes of consumers, but also contradictions in relation to the features of production technology, disadaptation of technological modes to differences in the composition and properties of domestic raw materials [7]. This, in its turn, caused the interest to the revival of cultured butter technology. The commercial success of probiotics at the market of soulmilk foods made developers appeal to other types of dairies, including cultured butter.

The strain of Lactobacillus acidophilus La-5 is a strain analogical to the one, that is in the gastrointestinal tract of people. La-5 is characterized by high firmness to muriatic and suckling acids during the long contact with them, that can considered as a guarantor of the maintenance of their viability at transit through the sour environment of stomach and at storage of soul-milk foods [8].

The maintenance of high level of viable amount of cells of probiotic in the fermented food products is not a simple task. The viability of cultures lactic acid bacterias is influenced by: acidity of product, co-operation of ferment cultures inter se and condition of their storage [9]. However, there are a few reports, that present sale milk products contain the insufficient amount of viable cages of probiotic (to $<10^{6} \mathrm{cfu} / \mathrm{g}$ on the dead-line of storage), the same way diminishing the positive influence on a health of man [10]. Thus, a survival of probiotics and development of methods for support of their vital functions during all expiration date are the important subject of researches.

In our time in the different countries around the world of Lactobacillus acidophilus is entered in a monoculture, or in a complex with the various types of lactobacilluss in composition of soul-milk foods $[11,12,13]$. The possibility and expediency of general cultivation of lactic acid bacterias and acidophilic bacillus are proven $[14,15,16]$, that allows to get the high concentration of viable cages of both groups of microorganisms in a product.

The once developed fermented dairy product is based on the use of cultures of Lactobacillus acidophilus La-5, Lactobacillus casei 431, BB-12 and Flora Danica. The 
best viable property, during the storage for temperature $4^{\circ} \mathrm{C}$, was characteristic feature of monoculture of Lactobacillus acidophilus La-5 in combination with the mixed cultures of Flora Danica $[17,18]$.

The rational correlation of lactic acid bacterias and acidophilic bacillus in a composition with ferment compositions may allow to produce acidophilic foods with the maximally high concentration of probiotic cultures, well organoleptics, rationed microbiological and physical and chemical indexes, in particular, with the not high level of acidity, and also prolonged expiration date [8].

Creams are the special environment for cultivation of lactate bacterias, and have marked features and temperature parameters of their fermentation for the production of butter, in addition, the special requirements are pulled out to the aroma and taste of cultured butter, that is why an important problem is forming of microbial composition.

The possibility of involving cultures of probiotic to fermentation of creams is an unstudied question. It needs the special attention from the point of view of temperature conditions and combination of processes of the biological and physical ripening of creams, as cultures for fermentation of creams are mesophilic, thus one should pick up strains with maximal activity at mionectic temperatures, and cultures of probiotic are thermophilic. For soul-milk foods with probiotic properties qualificatory is the viability of probiotic cultures and conservation of them in an amount that is necessary to give to the product the functional properties. Therefore, the determinations of conditions, at which the cultures of probiotic will save viability, simultaneously with forming the excellent organoleptic properties and rationed physical and chemical parameters are actual task [19].

The latest reports certify the positive connection between the consumption of full-milk and milk products, including, with high content of fat (butter) and health of people [20, 21].

The special attention is focused on sublimity of content of conjugated linoleic acids (CLA) in milk and milk products. CLA in milk preliminary appears in the deck-house of cattle as a mediator of microbal hydrogenation of polyunsaturated of fat acids. Except the microorganisms of scar, a few lactobacillus synthesize CLA [22, 23]. It is also reported that the synthesis of CLA by lactobacillus while enriching milk with oil rich for linolic acid as substrate [24]. It is determined that the synthesis of CLA by preparation that contained Lac. lactis (CI4b). The content of CLA increased from 0.41 to $1.21 \mathrm{~g} / 100 \mathrm{~g}$ of suckling fat in the fermented milk without addition of any substrates [25].

Without regard to considerable efforts of scientists, the content of CLA in the diets of people remains very low in the comparison with a level, necessary to provide the benefit for a health. Huth and other (2006) proved that $0.42 \mathrm{~g}$ of CLA in a day can result in anticarcinogenic effects for people. Strengthening of commercially accessible CLA-isomers that would become the effective method of increase of content of CLA in a dairy product, however, it is related with many defects, in particular, with the presence of other position of trans-isomers that show other effect, and also with the grant of taste defects [26]. The other authors in literature reports about the synthesis of CLA report a lactate microflora [27, 28, 29].

The search for ways of natural increase of content of CLA in dairy products is actual. One of them is the use of lactobacillus. This possibility to enrich CLA with dairy butter is unexplored.

A research aim was establishment of feature of cross-coupling of the cultures DVS Flora Danica and monoculture of probiotic L. acidophilus La-5 at a cultivation in creams while the production of cultured butter.

To reach a set aim, such tasks were solved: 
- to set possibility of combination of Flora Danica from L. acidophilus La-5 of fermentation of creams;

- to investigate influence of ferment cultures and temperature of fermentation of creams on activity of formation of lactic acid;

- to define influence of temperature of fermentation of creams on the amount of viable cages during fermentation and physical ripening of creams;

- to investigate influence of ferment cultures and temperature of fermentation of creams on composition of fatty acids of cultured butter;

- to give recommendations in relation to the scientific ground of technology of cultured butter with a probiotic properties.

\section{Materials and methods}

The firs research was conducted in the laboratory of the department of Milk and milk products technology at Lviv National University of Veterinary Medicine and Biotechnologies named after S.Z. Gzhytskyi and in the laboratory of CSK FOOD Enrichment-Ukraine. Milk raw material for the production of cultured butter was obtained in a spring-summer period of year. For this purpose used milk with mass part of fat 3,4\% was separated at a temperature $40-45^{\circ} \mathrm{C}$, received creams with mass part of fat $33 \%$ were pasteurized at a temperature $95{ }^{\circ} \mathrm{C}$ without a withstand. Creams after pasteurization were cooled to the temperature of fermentation.

It were applied two ferment cultures DVS for the fermentation of creams: cultures of Flora Danica - FD (Lactococcus lactis subsp. lactis; Lactococcus lactis subsp. cremoris; Lactococcus lactis subsp. lactis biovar. diacetylactis; Leuconostoc mesenteroides subsp. cremoris), and also monoculture of probiotic of Lactobacillus acidophilus La-5 - La-5 (Chr. Hansen, Denmark) in correlation 1:1, the initial concentration of cultures at a ferment in creams was $0,5 \cdot 10^{5}$ and $0,5 \cdot 10^{5} \mathrm{CFU} / \mathrm{ml}$ namely (for the standards of $\mathrm{K} 2$ and $\mathrm{K} 3$ ). For research four standards were made:

- sample 1 - CB1 accordingly - FD; the fermentation of creams at a temperature $20 \mathrm{C}$ and physical ripening at a temperature $5 \mathrm{C}$ is an initial concentration of cultures in creams $0,5 \cdot 10^{5} \mathrm{CFU} / \mathrm{ml}$;

- sample 2 - CB2 accordingly - FD in combination with La-5; fermentation of creams at a temperature $20^{\circ} \mathrm{C}$ and ripening at a temperature $5 \mathrm{C}$;

- sample 3 - CB3 accordingly - FD in combination with La-5; fermentation of creams at a temperature $30^{\circ} \mathrm{C}$ and ripening at a temperature $5{ }^{\circ} \mathrm{C}$;

- sample 4 - SB - sweet butter.

The activity of formation of lactic acid was selected the initial factors during fermentation of creams, that was determined after the change of titrated and active acidity, by the amount of viable cages in creams in $1 \mathrm{ml}$, organoleptic properties and composition of fatty acids of lipids of butter. Butter was made using the method of rafting of creams with a triple reiteration that was packed in polysterole glasses of the capacity of $200 \mathrm{ml}$ and kept for temperatures $0 \ldots 5 \mathrm{C}$.

The common amount of the mixed cultures of FD was determined the by the parallel sowing of breeding of standards of butter in double-dish on the environment of M17 Agar $\mathrm{CM}$ of a 0785 firm Himedia with next incubation in a thermostat at a temperature $30 \mathrm{C}$ during 3 days in anaerobic terms. Common amount of viable cells of La-5 was determined with the parallel sowing of breeding of standards of butter in double-dish on the 
environment of Lactobacillus MRS Agar M 641-500G (Himedia) with next incubation in a thermostat at a temperature $37 \mathrm{C}$ during 3 days in anaerobic conditions.

The composition of fat acids was investigated by the method of gas-liquid chromatography on gaschromatography of Hewlett Packard HP-6890 with application of capillary column of HP-88 (88 lyanopropyl aryl-polysiloxane, Agilent Technologies) length a $100 \mathrm{~m}$, with an internal diameter a $0,25 \mathrm{~mm}$ and in thick immobile phase of $0,2 \mathrm{m \kappa m}$ at next terms: flow rate of gas-transmitter-1,2 $\mathrm{ml} / \mathrm{min}$, coefficient of division of stream $1: 100$, temperature of vaporizer $-280{ }^{\circ} \mathrm{C}$, temperature of detector (UNDER) $-290{ }^{\circ} \mathrm{C}$, a temperature condition of column is the gradual heating from $60{ }^{\circ} \mathrm{C}$ to $230^{\circ} \mathrm{C}$.

It was used a mixture of methyl ethers of fat acids 37 Component FAME Mix firm of Supelco (executioner. № 47885-U) and mixture of methyl ethers of CLA firm of Sigma (executioner. № 05632) for authentication of chromatography peaks and account of chromatogram.

Registration and reatment of chromatogram was carried out by means of the personal computer equipped by HP ChemStation software.

\section{Results and discussion}

To establish the possibility of combination of FD with the acidophilic bacillus of strain of La-5 at making of cultured butter were conducted fermentation of creams at different temperatures, in fact a temperature has substantial influence on the dynamics of fermentation of creams, and in further on a organoleptic estimation and microbiological indexes of product. According to the review of literary data and technological instructions $[31,32]$ it is known that the optimal temperature of fermentation of creams at the production of cultured butter is a temperature of $16 \ldots 20{ }^{\circ} \mathrm{C}$. Taking into account the recommended for the cultures fermentation instructions and a compromise temperature for microbial cultures of selected preparations, were chosen two temperatures conditions 20 and $30^{\circ} \mathrm{C}$ for fermentation of creams.

The duration of hold of the leavened creams at every temperature depended on activity of ferment culture, namely speeds of growth of titrated acidity of plasma to the necessary value $-55^{\circ} \mathrm{T}$ (the value of titrated acidity directly for creams presents $37^{\circ} \mathrm{T}$ ), in obedience to a calculation driven to [32]. Cooling of the fermented creams began, when titrated acidity was on $8-10{ }^{\circ} \mathrm{C}$ [31] less than necessary, for avoidance of superfluous growth of acidity.

Titrated acidity of creams during fermentation for the standard of CB3 $(8 \mathrm{~h})$ grews from $17^{\circ} \mathrm{T}$ to $28^{\circ} \mathrm{T}$, while for $\mathrm{CB} 1$ and $\mathrm{CB} 2$ for $10 \mathrm{~h}$ to $25-26^{\circ} \mathrm{T}$. It was stablished that the greatest rate of increase of titrated acidity of creams is registered for the standard of CB3, for fermentation of that is used FD+La-5 and temperature of fermentation $30 \mathrm{C}$. During a $18 \mathrm{~h}$ of fermentation and physical ripening of creams titration for $\mathrm{CB} 3$ grew from $17^{\circ} \mathrm{T}$ to $37^{\circ} \mathrm{T}$, while for $\mathrm{CB} 2$ grew from $17^{\circ} \mathrm{T}$ to $31^{\circ} \mathrm{T}$ titration of creams $37^{\circ} \mathrm{T}$ answers $55^{\circ} \mathrm{T}$ acidity plasma. In the samples of $\mathrm{CB} 1$ and $\mathrm{CB} 2$, for fermentation of creams of that applied FD independently and combination with $\mathrm{La}-5$ and temperature $20^{\circ} \mathrm{C}$, the general duration of fermentation and physical ripening presented also $18 \mathrm{~h}$; during this time titration grew on $15^{\circ} \mathrm{T}$, while for $\mathrm{CB} 3$ on $20^{\circ} \mathrm{T}$. It is explained by subzero activity of FD and La- 5 for the temperatures of fermentation of creams $(20 \pm 1)^{\circ} \mathrm{C}$.

The maximum accumulation of diacetyl occurs at the active environment acidity $\mathrm{pH}$ 4.7-5.2 [33]. After the fermentation and physical maturation, the active cream acidity was within $\mathrm{pH}$ 5.56-5.22. Analogically to the volumetric change of acidity in the experimental 
samples of cream, the highest rate of decrease acidity active registered sample CB3, which is used for fermentation $\mathrm{FD}+\mathrm{La}-5$ and temperature $(30 \pm 1){ }^{\circ} \mathrm{C}$. During the cream fermentation in the sample cream CB2 active acidity for $10 \mathrm{~h}$ decreased by 0.87 whereas the sample $\mathrm{CB} 3$ for $8 \mathrm{~h}-$ by $\mathrm{pH} 0.94$.
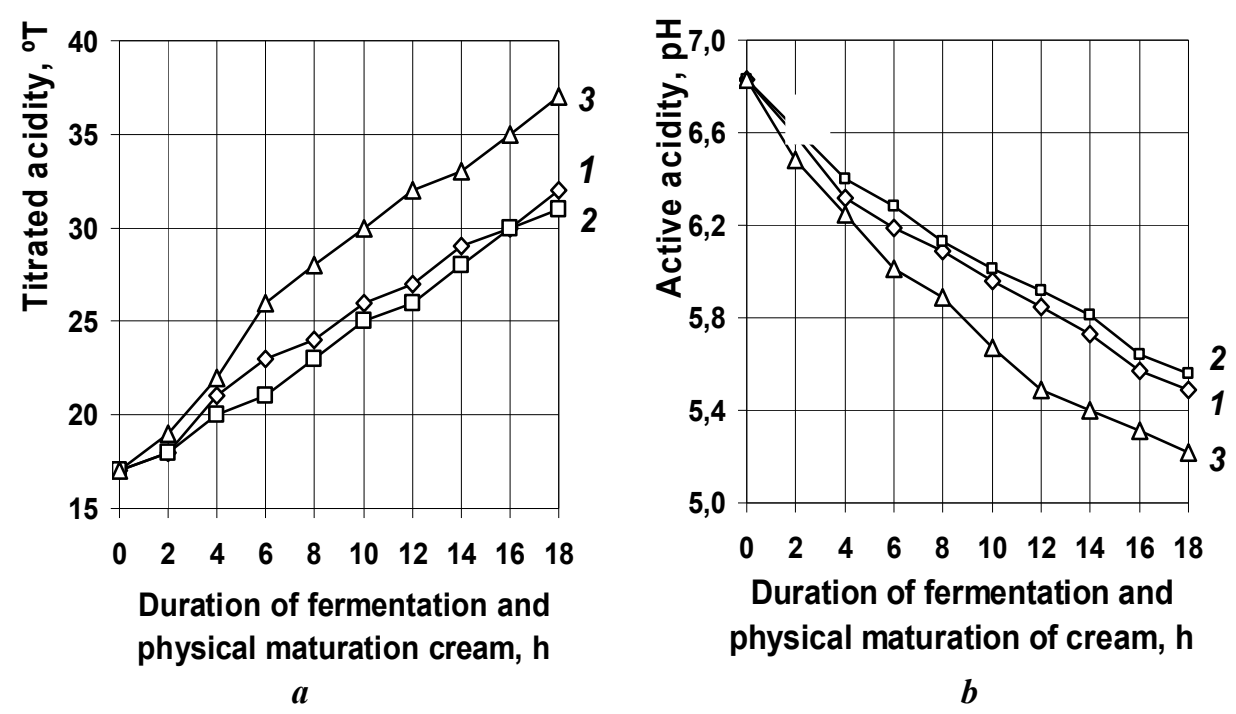

Fig. 1. Change of titrated (a), active (b) of acidity in the fermentation and physical maturation cream cultures FD and La-5:

1 -SB1; 2 -SB2; 3 - SB3.

At the beginning of the fermentation the number of viable cells FD and La-5 was $0.5 \cdot 10^{5} \mathrm{CFU} / \mathrm{cm}^{3}$ for all samples. While the fermentation of creams with the FD culture the at a temperature 20 and $30{ }^{\circ} \mathrm{C}$, the number of viable cells in samples CB1-CB3 $8 \ldots 10 \mathrm{~h}$ increased from 4.5 to $6.4-6,6 \mathrm{lg} \mathrm{CFU} / \mathrm{cm}^{3}$, and the number of cells La-5 (CB2-CB3) - up to 6.6-6.7 $\mathrm{lg} \mathrm{CFU} / \mathrm{cm}^{3}$. The usage of fermented cultures CB1-CB3 composed from FD and La-5, made it possible to get clusters of cream with the number of viable cells at the end of physical cream maturation FD 6.8-7.2 $\mathrm{lg} \mathrm{CFU} / \mathrm{cm}^{3}$, and $\mathrm{La}-5-7.0-7.4 \mathrm{lg} \mathrm{CFU} / \mathrm{cm}^{3}$. The most intensive increase in the number of viable cells occurred during the fermentation of cream; in the future, the number of viable cells has changed slightly, due to the low activity of cultures at low temperature of physical maturation $(5 \pm 1){ }^{\circ} \mathrm{C}$. However, as it is certified by the results, sample with the joint cultivation of FD and La-5 at a fermentation temperature $(30 \pm 1)^{\circ} \mathrm{C}$ shows the best dynamics, because the concentration of viable cells in this version was the largest.

However, in all tested items such number of viable cells is insufficient to ensure the probiotic properties of the finished product - cultured butter, since the further technological operations connected with the removal of plasma, thus, significant decrease in the number of viable cells. Therefore, further studies are required to search the dose of inoculation of fermented cultures and immediate introduction of FD and La-5 and determination of their value to increase the concentration of viable cells. 


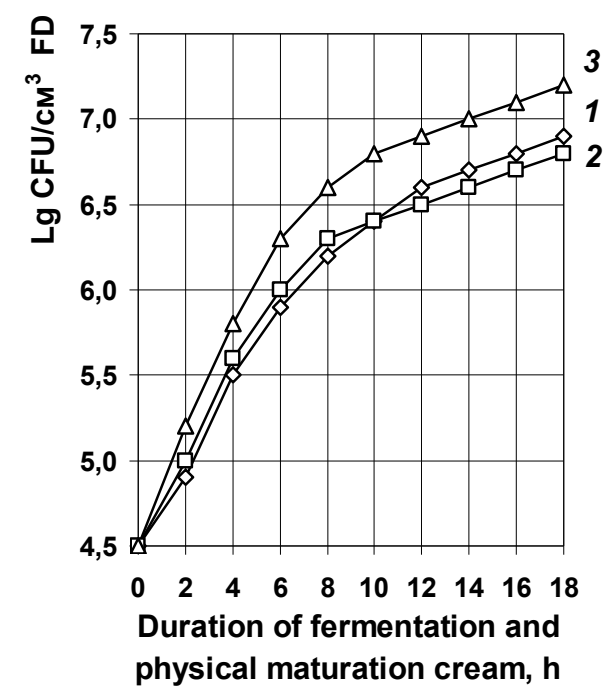

$a$

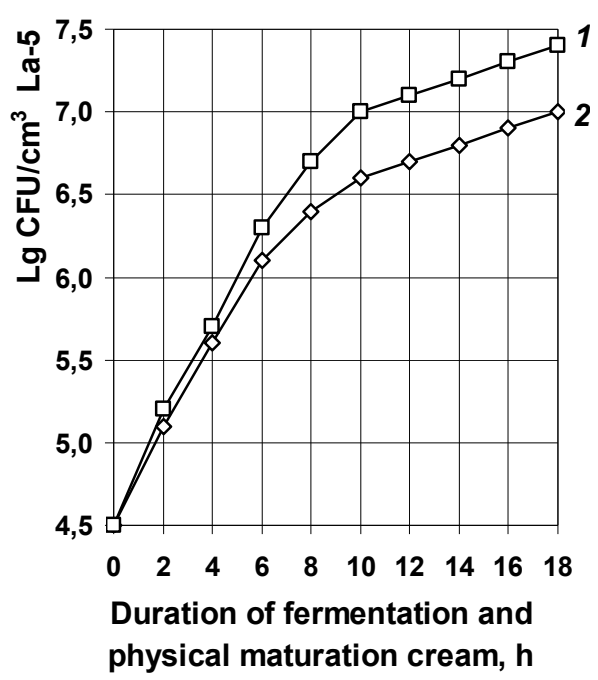

b

Fig. 2. Change of the number of viable cells FD (a) and La-5 (b) $1 \mathrm{~cm}^{3}$ cream during fermentation and physical maturation cream cultures DVS

\section{Organoleptic butter samples}

Table 1

\begin{tabular}{|c|l|}
\hline Samples of butter & \multicolumn{1}{c|}{ Characterization } \\
\hline SB & $\begin{array}{l}\text { Clean, with characteristic pleasant taste and aroma from pasteurized } \\
\text { cream flavor. Homogeneous, plastic, solid surface butter on the cut } \\
\text { shiny and dry in appearance to the presence of single the smallest } \\
\text { droplets of moisture. Color yellow, uniform throughout the mass of } \\
\text { color. }\end{array}$ \\
\hline CB1 & $\begin{array}{l}\text { Insufficiently pronounced sour taste and smell. Homogeneous, not } \\
\text { enough plastic, solid surface butter on the cut slightly shiny and dry } \\
\text { in appearance to the presence of single the smallest droplets of } \\
\text { moisture. Color light yellow, homogeneous throughout the mass. }\end{array}$ \\
\hline CB2 & $\begin{array}{l}\text { Clean, without the tastes and smells of weakly expressed yogurt } \\
\text { taste and smell. Homogeneous, plastic, solid surface butter on the } \\
\text { cut slightly shiny and dry in appearance to the presence of single the } \\
\text { smallest droplets of moisture. Color light yellow, homogeneous } \\
\text { throughout the mass. }\end{array}$ \\
\hline CB3 & $\begin{array}{l}\text { Clean, without the tastes and smells of the expressed pleasant } \\
\text { yogurt flavor and aroma. Homogeneous, plastic, solid surface butter } \\
\text { on the cut shiny and dry in appearance to the presence of single the } \\
\text { smallest droplets of moisture. Color yellow, uniform throughout the } \\
\text { mass of color. }\end{array}$ \\
\hline
\end{tabular}


Table 2

Fat acid composition of lipids in samples CB1-CB3, compared with sweet butter, \% of total fat acids

\begin{tabular}{|c|c|c|c|c|}
\hline \multirow[t]{2}{*}{ Fat acids } & \multicolumn{4}{|c|}{ Samples of butter } \\
\hline & SB & CB1 & CB2 & CB3 \\
\hline $\mathrm{C} 4: 0$ & 4.07 & $4.42 *$ & $4.35^{*}$ & $4.42 *$ \\
\hline C6:0 & 1.59 & 1.67 & 1.67 & 1.67 \\
\hline $\mathrm{C} 8: 0$ & 0.93 & 0.96 & 0.96 & 0.96 \\
\hline C10:0 & 1.99 & 2.02 & 2.04 & 2.03 \\
\hline C12:0 & 2.40 & 2.42 & 2.45 & 2.44 \\
\hline C14:0 & 9.56 & 9.59 & 9.63 & 9.58 \\
\hline iso-C14:0 & 0.45 & 0.45 & 0.45 & 0.45 \\
\hline anteiso-C14:0 & 0.81 & - & - & - \\
\hline C14:1 & 0.97 & $1.74 * *$ & $1.74 * *$ & $1.74 * *$ \\
\hline $\mathrm{C} 15: 0$ & 1.57 & 1.57 & 1.57 & 1.56 \\
\hline C16:0 & 25.04 & 24.96 & 24.96 & 24.82 \\
\hline iso- $\mathrm{C} 17: 0$ & 0.78 & 0.77 & 0.77 & 0.77 \\
\hline C16:1 c9 & 1.40 & 1.39 & 1.40 & 1.41 \\
\hline anteiso-C17:0 & 0.58 & 0.58 & 0.58 & 0.58 \\
\hline $\mathrm{C} 17: 0$ & 0.91 & 0.90 & 0.90 & 0.90 \\
\hline C18:0 & 11.29 & 11.22 & 11.19 & 11.10 \\
\hline C18:1 t6 & 0.33 & 0.28 & 0.30 & 0.33 \\
\hline C18:1 t9 & 0.26 & 0.29 & 0.28 & 0.24 \\
\hline C18:1 t11 & 4.03 & 4.01 & 3.99 & 4.00 \\
\hline C18:1 c6 & 0.26 & 0.24 & 0.26 & 0.24 \\
\hline C18:1 c9 & 22.82 & $22.66^{*}$ & $22.67 *$ & 22.71 \\
\hline C18:1 c11 & 0.63 & 0.62 & 0.62 & 0.62 \\
\hline C18:1 c12 & 0.15 & 0.15 & 0.15 & 0.15 \\
\hline C19:0 & 0.14 & - & - & 0.14 \\
\hline $\mathrm{C} 18: 2 \mathrm{t} 9, \mathrm{c} 12$ & 0.12 & 0.12 & 0.12 & 0.12 \\
\hline $\mathrm{C} 18: 2 \mathrm{c} 9, \mathrm{t} 12$ & 0.62 & 0.61 & 0.60 & 0.61 \\
\hline $\mathrm{C} 18: 2 \mathrm{c} 9, \mathrm{c} 12$ & 1.33 & 1.32 & 1.33 & 1.33 \\
\hline $\mathrm{C} 20: 0$ & 0.24 & 0.23 & 0.23 & 0.23 \\
\hline $\mathrm{C} 18: 3 \mathrm{c} 9, \mathrm{c} 12, \mathrm{c} 15$ & 1.22 & 1.21 & 1.21 & 1.21 \\
\hline C 20:1 c11 & 0.21 & 0.21 & 0.20 & 0.21 \\
\hline C18:2 CLA c9, t11 & 1.84 & 1.92 & 1.87 & $1.93 *$ \\
\hline $\mathrm{C} 18: 2 \mathrm{c} 10, \mathrm{c} 12$ & 0.02 & 0.01 & 0.01 & 0.01 \\
\hline $\mathrm{C} 18: 2 \mathrm{t} 10, \mathrm{c} 12$ & 0.01 & 0.01 & 0.02 & 0.01 \\
\hline C18:2CLA c11, t13 & 0.14 & 0.14 & 0.14 & 0.13 \\
\hline $\mathrm{C} 21: 0$ & - & 0.08 & 0.08 & 0.05 \\
\hline C18:2 CLA c9, c11 & 0.03 & 0.02 & 0.02 & 0.03 \\
\hline C18:2 CLA t11, t13 & 0.02 & 0.02 & 0.02 & 0.02 \\
\hline $\mathrm{C} 20: 2$ & 0.03 & 0.03 & 0.02 & 0.02 \\
\hline C18:2 CLA t9, c11 & 0.09 & 0.11 & 0.09 & 0.11 \\
\hline $\mathrm{C} 22: 0$ & 0.15 & 0.12 & 0.12 & 0.12 \\
\hline $\mathrm{C} 20: 3 \mathrm{c} 8, \mathrm{c} 11, \mathrm{c} 14$ & 0.05 & 0.08 & 0.07 & 0.07 \\
\hline $\mathrm{C} 20: 3 \mathrm{c} 11, \mathrm{c} 14, \mathrm{c} 17$ & 0.02 & 0.03 & 0.03 & 0.02 \\
\hline $\mathrm{C} 20: 4 \mathrm{c} 5 \mathrm{c} 8, \mathrm{c} 11, \mathrm{c} 14, \mathrm{c} 17$ & 0.11 & 0.12 & 0.13 & 0.13 \\
\hline $\mathrm{C} 23: 0$ & 0.08 & 0.08 & 0.07 & 0.07 \\
\hline $\mathrm{C} 20: 4$ & 0.10 & 0.10 & 0.10 & 0.09 \\
\hline $\mathrm{C} 20: 5 \mathrm{c} 5, \mathrm{c} 8, \mathrm{c} 11, \mathrm{c} 14, \mathrm{c} 17$ & 0.14 & 0.14 & 0.15 & $0.22 *$ \\
\hline $\mathrm{C} 24: 0$ & 0.09 & 0.09 & 0.09 & 0.09 \\
\hline $\mathrm{C} 22: 5 \mathrm{c} 7, \mathrm{c} 10, \mathrm{c} 13, \mathrm{c} 16, \mathrm{c} 19$ & 0.30 & 0.31 & 0.32 & 0.29 \\
\hline
\end{tabular}

Note: ${ }^{*}$ - the difference is likely to control $*-\mathrm{P}<0.05 ; * *-\mathrm{P}<0.01 ; * * *-\mathrm{P}<0.001$ 
According to the organoleptic evaluation, sample CB3 with a combination of cultures $\mathrm{FD}$ and $\mathrm{La}-5$ and fermentation at a temperature $30^{\circ} \mathrm{C}$ was characterized with clean, without the other tastes and smells of the expressed pleasant yogurt flavor and aroma. Other samples were characterized by insufficient or poorly marked yogurt flavor and aroma. Sweet butter is characterized by a pleasant taste and aroma from pasteurized cream flavor. Color samples of oil from light yellow to yellow, homogeneous throughout the mass.

Therefore, to development of promising technologies of cultured butter with probiotic properties are the composition of FD and La-5 and fermentation temperature of fermentation cream $-(30 \pm 1)^{\circ} \mathrm{C}$.

The fermentation of creams cultures of immediate introduction of DVS FD and La-5 while cultured butter production affected the fat acid composition of milk fat, as evidenced by the data presented in table 2 .

The results show that sweet butter and cultured butter are characterized by a large range of fat acids, which include acids iso-forms and anteiso, as well as acid chain of length of more than 20 carbons $(\mathrm{C} 21: 0, \mathrm{C} 22: 0, \mathrm{C} 23: 0, \mathrm{C} 24: 0)$. The main changes include increasing the proportion of butyric acid (C4:0) $8.6 \%$ for CB1 and CB3 $(\mathrm{p}<0.05)$ and $6.9 \%$ for CB2 $(p<0.05)$, respectively, compared with sweet butter. This is a unique milk fat acid which shows anticarcinogenic effect, synthesized de novo in the secretory cells of the breast and is the dominant short-fatty acids of milk lipids ruminants.

Typical components of milk fat are fatty acids with branched carbon chain (iso-C14:0, anteiso-C14:0, iso-C17:0, anteiso-C17:0), which are components of lipid microbial cells. The largest number of this group of acids in the butter sample SB was acid anteiso-C14:0. In samples of cultured butter this acid was not identified.

The most undesirable fat acids of milk fat is saturated C12:0, C14:0 and C16:0, because they contribute to raising the level of cholesterol and low-density lipoprotein in the blood and thus show atherogenic and thrombogenic properties. The content of acid C14:1 in samples of cultured butter increased by 2 times that may be a sign of activity of desaturated microflora under the influence of $\Delta 9$-desaturasy. Among the family of acids $\mathrm{n}-6$ in samples of butter dominated linoleic $(\mathrm{C} 18: 2 \mathrm{c} 9, \mathrm{c} 12)$, the content of which was 1.32$1.33 \%$.

The presence in dairy products trans-isomers of unsaturated fat acids is associated with the risk to human health. However, the main trans-acids of milk fat is C18:1 trans-11 and dienes trans-11 conjugated of linoleic acid, exhibiting the diverse positive biological effects on the human body. The most studied linoleic acid isomer is cis-9, trans-11 diene conjugates that has anticarcinogenic, antiatherogenic, antidiabetic, anti-inflammatory and immunomodulatory effects $[36,37]$. The results showed that the content of CLA cis-9, trans- 11 consisting in milk fat was $1.84 \%$ in SB and $1.92,1.87,1.93 \%$ respectively in CB1, $\mathrm{CB} 2$, CB3. The sum of all isomers CLA in the experimental samples of butter ranged from 2.08 to $2.13 \%$, it should be emphasized that the content of trans-9 isomers in a CB3 was 0.24 versus 0.26 in SB. The content of cis-9, trans-11 CLA showed a tendency to increase in samples CB1 and CB3. These results of the content of trans-11 isomer in the sample CB2 may pressupose that the joint cultivation of lactic acid bacteria FD and acidophilic bacillus probiotic strains $\mathrm{La}-5$ at a fermentation temperature $(30 \pm 1){ }^{\circ} \mathrm{C}$ these isomers are synthesized by lactic acid bacterias.

The increase of unsaturated fat acids in the samples of cultured butter reflected in the tendency to increase the ratio of unsaturated/saturated fat acids -0.61 in CB1-CB3 versus 0.59 in SB. In the butter samples the total content of branched fat acids ranged within 1.8$2.6 \%$ of the sum of fat acids. The sum of odd fat acids was similar in all groups as well. 
The ratio of fatty acids n-3/n- 6 were roughly the same in all tested items, but the amount of families acids $n-3$ and $n-6$ showed a tendency to increase in samples of cultured butter.

As for the content of fatty acids that exhibit a strong biological effects, their contents showed a clear tendency to increase the sample of cultured butter CB3, in which were used a combination of mixed cultures of mesophilic and thermophilic acidophilic bacillus fermentation and cream at temperature $(30 \pm 1)^{\circ} \mathrm{C}$.

\section{Conclusions}

The possibility of a combination of mixed cultures of Flora Danica and L. acidophilus La-5 strain during fermentation of cream in the technology of cultured butter was determined.

Fat acid composition of samples butter was researched. As for the content of fatty acids that exhibit a strong biological effects, their contents showed a tendency to increase in the sample of cultured butter, in which was used a combination of mixed cultures of mesophilics lactic acid bacterias and thermophilic acidophilic bacillus and cream fermentation at temperature $(30 \pm 1)^{\circ} \mathrm{C}$.

It was proposed to use in the technology of a cultured butter, ferment composition, composed from mixed mesophilic cultures FD and thermophile La-5 and a temperature of cream fermentation of $(30 \pm 1)^{\circ} \mathrm{C}$.

\section{References}

1. Diplock A.T., Aggett P.J., Ashwell M.A. et al. (1999), Scientific concept of functional foods in Europe: consensus document, British Journal of Nutrition, 81 (1), pp. 1-27.

2. Richardson D.P. (2002), Functional Food and Health Claims, The world of Functional ingredients, 9, pp. 12-20.

3. Roberfroid M.B. (2002), Global view on functional foods: European perspectives, British Journal of Nutrition, 88 (2), pp. 133-138.

4. Tkachenko N.A., Skrypnichenko D.M. (2014), Obgruntuvannya racionalnogo vmistu molokozsidalnogo fermentu SNU-MAX u vyrobnycztvi myakyx probiotychnyx syriv, Xarchova texnologiya ta promyslovist, 2(27), pp. 24-29.

5. Gavalko Y.V., Gavalko A.V. (2015), Dosvid vykorystannya probiotykiv pry metabolichnomu syndromi u lyudej litnogo viku, Mizhnarodnyj nacionalny j kongres «Lyudyna ta liky».

6. Tkachenko N.A., Nazarenko Y.V., Avershyna A.S., Ukrayinceva Y.S. (2014), Zakvashuvalni kompozyciyi dlya dytyachyx kyslomolochnyx produktiv z pidvyshhenymy proteolitychnymy vlastyvostyamy, Sxidno-Yevropejskyj zhurnal peredovyx texnologij, 12 (68), pp. 66-71.

7. Vyshemyrskyj F.A. (2006), «Maslo yz vershkov», Syrodelye y maslodelye, 1, pp. 25-28.

8. Didux N.A., Chagarovskyj O.P., Lysogor T.A. (2008), Zakvashuvalni kompozyciyi dlya vyrobnycztva molochnyx produktiv funkcionalnogo pryznachennya, Poligraf, $233 \mathrm{p}$.

9. Gilliland S.E., Reilly S.S., Kim G.B., Kim H.S. (2002), Viability During Storage of Selected Probiotic Lactobacilli and Bifidobacteria in a Yogurt-like Product, Journal of Food Science, 67, pp. 3091-3095.

10. Tharmaraj N., Shah N.P. (2003), Selective Enumeration of Lactobacillus delbrueckii ssp. bulgaricus, Streptococcus thermophilus, Lactobacillus acidophilus, Bifidobacteria, Lactobacillus casei, Lactobacillus rhamnosus, and ropionibacteria, Journal of Dairy Science, 86, pp. 22882296.

11. Kaushal D., Kansal V.K. (2014), Dahi containing Lactobacillus acidophilus and Bifidobacterium bifidum improves phagocytic potential of macrophages in aged mice, Food Science and Technology, 51(6), pp. 1147-1153. 
12. Lavinia B., Nicolescu C., Avram D., Gabriela M. (2009), Survival of probiotic bacteria during lactic acid fermentation of vegetable juices, Journal of Agroalimentary Processes and Technologies, 15(1), pp. 132-139.

13. Zhou J.S., Shu Q., Rutherfurd K.J., Prasad J., Birtles M.J., Gopal P.K., Gill H.S. (2000), Safety assessment of potential probiotic lactic acid bacterial strains Lactobacillus rhamnosus HN001, Lb. acidophilus HN017, and Bifidobacterium lactis HN019 in BALB/c mice, International Journal of Food Microbiology, 56(1), pp. 87-96.

14. Romanchuk I.O. (2001), Rozrobka texnologiyi zakvashuvalnyx preparativ pryamogo vnesennya dlya jogurtu ta smetany, PhD Thethis, Kyiv.

15. Burns G., Vinderola A., Binetti A., Quiberoni C.G., de los Reyes-Gavilán (2008), Bile-resistant derivatives obtained from non-intestinal dairy lactobacilli, International Dairy Journal, 18(4), pp. 377-385.

16. Dianawati D., Vijay M., Shah P. (2013), Nagendra Effect of drying methods of icroencapsulated Lactobacillus acidophilus and Lactococcus lactis ssp. cremoris on secondary protein structure and glass transition temperature as studied by Fourier transform infrared and differential scanning calorimetry, Journal of Dairy Science, 96(3), pp. 1419-1430.

17. Lourens-Hattingh A., Viljoen B.C. (2001), Yogurt as probiotic carrier food, International Dairy Journal, 11, pp. 1-17.

18. Paraschiv D., Vasile A., Constantin M., Ciobanu A., Bahrim G. (2011), Study of physiological properties of some probiotics in multiple cultures with mesophilic lactis acid bacteria by Flora Danica Ch. Hansen commercial starter, Food Technology, 35(2), pp. 56-65.

19. Tkachenko N.A., Nazarenko Y.V., Okunevska S.O. (2015), Racionalne spivvidnoshennya kultur laktobakterij u biotexnologiyi kyslomolochnyx produktiv dlya lyudej z sercevo-sudynnymy zaxvoryuvannyamy, Xarchova nauka i texnologiya, 9 (3), pp. 16-22.

20. Gaver L., Winston D. (2007), Dairy products shown to help reduce blood pressure, Journal of Dairy Science, 90, pp. 186.

21. Palacios O.M., Nicholls J., Green R., Miller G.D. (2007), Invited editorial: The importance of dairy foods in helping impoverished people in the United States, Journal of Dairy Science, 90, pp. 4917-4923.

22. Ogawa J., Kishino S., Ando A., Sugimoto S., Mihara K., Shimizu S. (2005), Production of conjugated fatty acids by lactic acid bacteria, Journal of Bioscience and Bioengineering, 100, pp. 355-364.

23. Rodriguez-Alcala L.M., Braga T., Malcata F.X., Gomes A., Fontecha J. (2011), Quantitative and qualitative determination of CLA produced by Bifidobacterium and lactic acid bacteria by combining spectrophotometric and Ag+-HPLC techniques, Food Chemistry, 125, pp. 13731378 .

24. Andrade J.C., Ascencao K., Gullon P., Henriques S.M.S., Pinto J.M.S., Rocha-Santos T.A.P., Freitas A.C., Gomes A.M. (2012), Production of conjugated linoleic acid by food-grade bacteria: A review, International Journal of Dairy Technology, 65, pp. 467-481.

25. Pandit A., Anand S., Kalscheur K., Hassan A. Production of conjugated linoleic acid by lactic acid bacteria in milk without any additional substrate, International Journal of Dairy Technology, 65, pp. 603-608.

26. Campbell W., Drake M.A., Larick D.K. (2003), The impact of fortification with conjugated linoleic acid (CLA) on the quality of fluid milk, Journal of Dairy Science, 86, pp. 43-51.

27. Domagala J., Sady M., Najgebauer-Lejko D., Czernicka M., Wieteska I. (2009), The content of conjugated linoleic acid (CLA) in cream fermented using different starter cultures, Biotechnology in Animal Husbandry, 25 (5-6), pp. 745-751.

28. Jiang J., Bjorck L., Fonden R. (1998), Production of conjugated linoleic acid by dairy starter cultures, Journal of Applied Microbiology, 85, pp. 95-102.

29. Mohan M.S., Anand S., Kalscheur K.F., Hassan A.N., Hippen A.R. (2013), Starter cultures and cattle feed manipulation enhance conjugated linoleic acid concentrations in Cheddar cheese, Journal of Dairy Science, 96(4), pp. 2081-2094. 
30. Sieber R., Collomb M., Aeschlimann A., Jelen P., Eyer H. (2004), Impact of microbial cultures on conjugated linoleic acid in dairy products-a review, International Dairy Journal, 14(1), pp. $1-15$.

31. Gryshhenko A.D. (1983), Slyvochnoe maslo, Moscow

32. (1980) Sbornyk texnologicheskix instruktcij po proizvodstvu slivochnogo i toplenogo masla, CNTY.

33. O'Sullivan D.J. (2001), Screening of intestinal microflora for effective probiotic bacteria, Journal of Agricultural and Food Chemistry, 49, pp. 1751-1760.

34. Kostova I., Damyanova S., Ivanova N., Stoyanova A., Ivanova M., Vlaseva R. (2016), Use of Essential Oils in Dairy Products. Essential Oil of Basil (Ocimum basilicum L.), Indian Journal of Applied Research, 6(1), pp. 211-213.

35. Kostova I., Damyanova S., Ivanova N., Stoyanova A., Ivanova M., Vlaseva R. (2016), Use of essential oils in dairy products. 2. Essential oil of caraway (Carum carvi L.), Journal of Food and Packaging Science, Technique and Technologies, 8, pp 20-23.

36. Belury M.A. (2002), Dietary conjugated linoleic acid un health: Physiological effects and mechanisms of action, The Annual Review of Nutrition, pp. 505-531.

37. Parodi P.W. (1999), Conjugated linoleic acid and other anticarcinogenic agents of bovine milk fat, Journal of Dairy Science, 82, pp. 1339-1349. 